ЛЕГІТИМІЗАЦІЯ МОБІНГУ СЕРЕД ДІТЕЙ: СПРОБА АНАЛІЗУ ПРОБЛЕМИ

\title{
LEGITIMIZATION OF MOBBING AMONG CHILDREN: AN ATTEMPT TO ANALYZE THE PROBLEM
}

У статті зроблено спробу проаналізувати індивідуальні процеси послаблення стримувальних механізмів мобінгу серед дітей, зокрема виправдання, легітимізації насильства та девіантної агресії. У результаті огляду досліджень мобінгу серед дітей з'ясовано, що влада над жертвою, кругова порука й легітимізація насильства є потужними детермінантами цього явища.

Мu намагалися проаналізувати механізми легітимізації мобінгу, а саме: заперечення відповідальності (у цьому випадку мобер презентує себе як жертву обставин, заперечує свій злий умисел або ж перекладає вину на інших); заперечення або мінімізацію завданої шкоди (коли відповідальності за скоєне уникнути не вдається, здійснюється прийом заперечення чи мінімізації шкоди); заперечення або екскатегоризацію жертви (у ситуаціях неможливості уникнення відповідальності за скоєне та заперечити або мінімізувати заподіяну шкоду мобер переключає свою увагу на жертву); осуд засуджуючих (мобер переключає увагу на тих, хто його засуджує, заперечуючи їхнє право на оцінювання); нейтралізацію девіантної оцінки поведінки посиланням на більш високі цінності (виправдання здійснюється через обгрунтування своїх дій вищими цінностями або необхідністю дотримуватися групових норм).

3 метою уточнення проблеми легітимізаціі та виправдання мобінгу автором проведено дослідження серед учнів і з'ясовано, що більшість респондентів уважає насильницьку поведінку необхідною в деяких випадках; підтвердила, що невинні жарти переважно переходять у відкрите кепкування; потрапляла в ситуації, коли гуртом з іншими провчили «невдаху». Виявлено зв'язок між звичкою придумувати смішні прізвиська іншим і рівнем легітимізації агресії за шкалами опитника «ЛА-44»: власний досвід, спорт, ЗMI, інтегральна шкала.

Зазначено, що легітимізація мобінгу - це обгрунтування прийнятності, виправданості й необхідності своїх тривалих насильницьких чи агресивних посягань, цькування жертви, а також виправдання себе і своєі ролі в процесі мобінгу, надання своїм діям ознак «нормальності» й «законності» за допомогою вищенаведених механізмів. При цьому специсріка явища мобінгу та його структура передбачають певні механізми легітимізації, які включено в його сутність.
Ключові слова: мобінг, виправдання, легітимізація, насильство, агресія, легітимізація мобінгу.

The article attempts to analyze individual processes of weakening the deterrent mechanisms of mobbing among children, including justification, legalization of violence and deviant aggression. A review of research on mobbing among children found that power over the victim, circular bail, and the legitimization of violence are powerful determinants of this phenomenon.

The article analyzes the mechanisms of legitimizing mobbing, namely: denial of responsibility (in this case, the mob presents himself as a victim of circumstances, denies his malicious intent or shifts the blame on others); denial or minimization of the caused damage (when responsibility for the committed cannot be avoided, reception of denial or minimization of damage is carried out); denial or excategorization of the victim (in situations of impossibility to avoid responsibility for the act and to deny or minimize the damage, the mobster switches his attention to the victim); condemnation of convicts (mobster switches attention to those who condemn him, denying their right to evaluation); neutralization of deviant assessment of behavior by reference to higher values (justification is carried out by justifying their actions with higher values or the need to adhere to group norms).

In order to clarify the problem of legitimization and justification of mobbing, the author conducted a survey among students and found that most respondents: believe that violent behavior is necessary in some cases; confirmed that innocent jokes mostly turn into open mockery; found themselves in a situation where a group with others studied the "loser". The connection between the habit of coming up with funny nicknames for others and the level of legitimization of aggression on the scales of the questionnaire " $L A-44$ ": own experience, sports, media, integrated scale. The article shows that the legitimization of mobbing is a justification of the acceptability, justification and necessity of their long-term violent or aggressive encroachment, harassment of the victim, as well as justifying themselves and their role in mobbing, giving their actions signs of "normalcy" and "legality" by the help of mechanisms mentioned above. The specifics of the phenomenon of mobbing and its structure provide certain legitimizing mechanisms, which are included in its essence.

Key words: mobbing, justification, legitimization, violence, aggression, legitimization of mobbing.

ДВНЗ «Ужгородський національний університет»

Постановка проблеми. Актуальність вивчення й детального аналізу проблеми агресії та насильства серед дітей сьогодні не викликає сумніву ні в кого. Найбільш небезпечними за своїми наслідками проявами агресії та насильства є булінг і мобінг серед неповнолітніх. Випадки знущань серед дітей набувають значних масштабів з появою нових форм і видів цькувань жертви за допомогою інноваційних інформаційних технологій, комунікативних каналів і соціальних мереж. Явище мобінгу ґрунтується на двох процесах: переслідувачі встановлюють і підтримують свою владу, знущаючись над жертвою, що супро- 
воджується також відчуттям єднання з групою та груповою відповідальністю, а також індивідуальним процесом послаблення стримуючих механізмів від вчинків, які засуджуються суспільством. Основною технікою послаблення стримуючих механізмів є виправдання й легітимізація вчинків, які в суспільстві традиційно вважаються девіантними. У часи суспільної кризи та емоційного напруження, яких зазнало наше суспільство сьогодні, а також в умовах вибіркових механізмів реагування на девіантні форми агресивної й насильницької поведінки особливо актуальними є питання легітимізації та виправдання насильницьких посягань, зокрема мобінгу серед дітей.

Аналіз останніх досліджень і публікацій. Питаннями легітимізації та виправдання насильницької поведінки цікавилися А. Бандура, Р. Уолтерс, Л.Р. Х'юзман, Л. Ерон, Е. Руланн, Г. Сайкс, Д. Матца, С. Еніколопов, М. Цибульський, Бушман, Є. Головаха. Соціальні проблеми застосування насильства й проявів агресії серед дітей досліджують Л. Розе-Краснор, Г. Гіні, М. Кірпка, Н.Р. Крік, К.А. Додж, В. Бернер, К. Шмек, К. Галвег, Н. Гойер, С. Науман, А. Шік, І. Отт, Г. Шмід, Е. Кунче, С. Анлікер, Г. Боденманн, Б. Фей. Дослідженням мобінгу присвятили праці Д. Олвеус, Е. Руланн, Г. Гіні, Х. Лейман, Х. Хайнеман, Ф.Д. Алзакер, П.К. Сміт, К.Е. Дамбах, А. Баумгартнер, А. Фонці, Ю. Філіппова, О. Качмар, К. Колодей та інші.

Постановка завдання. У статті ми намагалися проаналізувати індивідуальні процеси послаблення стримуючих механізмів насильства серед дітей, зокрема виправдання й легітимізації мобінгу.

Виклад основного матеріалу дослідження. Мобінг, за визначенням Д. Олвеуса, - це цькування, коли група індивідів регулярно протягом тривалого часу здійснюють фізичні чи соціальні негативні дії, спрямовані на іншого індивіда чи групу, які не можуть захистити себе в поточній ситуації [1]. Мобінг - це мотивоване заподіяння шкоди жертві групою осіб, що має системний і тривалий характер. Е. Руланн пояснює мобінг через модель взаємодії моберів, жертви, спостерігачів, що вписана в систему контекстних факторів: класу, школи, суспільства. Центральне місце моделі посідає клас учнів з їхніми особистісними характеристиками, ефективність навчання, а також цінності, норми та правила, ситуація в сім'ях учнів. Учителю відведено важливу й керівну роль, окремо відмічено його зв'язок із класом і сім'ями учнів, а також колегами та керівництвом освітнього закладу [2].

Дослідження К. Доджа й Е. Роланда доводять, що предиктором мобінгу в основному $€$ саме проактивна, а не інструментальна агресія. Тобто джерелом агресії та насильства є не певні зовнішні причини чи обставини, а сам мобер. Постійному відтворенню й посиленню мобінгу сприяють також специфічні сценарії переробки інформації та інтерпретації ситуацій [3], частиною якихє частковеабо повневиправдання девіантного агресивного й насильницького поводження, так звана легітимізація одиничних актів мобінгу та процесу загалом.

Поняття «легітимізація насильства» С.М. Еніколопов визначає як «процес обґрунтування прийнятності й виправдання різних форм агресивної поведінки шляхом атрибуції суспільно схвалюваного (легітимного) статусу» [4]. Г. Сайкс і Д. Матза в рамках теорії нейтралізації стверджували, що основною причиною девіантної поведінки може бути ставлення особи до соціальних норм. Особа, яка скоїла девіантний вчинок (насильство), щоб звільнити себе від відповідальності й тягаря «неправильного» вчинку, може «нейтралізувати» дію порушених норм певними механізмами [5]. До технік послаблення та нівелювання стримуючих механізмів належить саме виправдання й легітимізація насильства. Девіантологія розглядає насильство як відхилення від норми або ідеалу. Слабким місцем девіантології $€$ інтуїтивність або конвенційність поняття норми. Завдяки конвенції норму не можна визнати чиєюсь суб'єктивною вигадкою. Норма погоджується на мега- або мезосоціальному рівнях. Проте на мікрорівні, де можливо інтуїтивне визнання норм насильницького поводження, вона може бути суб'єктивним явищем. Насильство на мікрорівні проявляється у формі свідомого впливу на особу поза її волею та бажанням, що призводить до обмеження чи втрати нею можливостей для власного розвитку. У силу того що насильство завжди несе порушення здоров'я або загрозу його порушення, воно проявляється як соціально небезпечне явище.

Відомо, що насильство є одним із так званих історично сформованих «засобів» самоствердження та набуття почестей. Воно знаходиться поряд із такими важливими ресурсами для суспільного визнання, як влада та багатство. Неминуча соціальна й економічна нерівність завжди зумовлюватимуть насильство як метод боротьби індивідів за підвищення статусу та економічних позицій. Проте варто пам'ятати, що насильство як спосіб адаптації, проникаючи в усі сфери життя, виходячи 3-під контролю, загрожує масштабними негативними наслідками [6].

Дослідження ілюструють, що в більшості випадків мобінг серед дітей є саме засобом здобутку, утримання чи підвищення своєї соціальної позиції серед однолітків і значимого оточення [7].

Відомий дослідник мобінгу в закладах освіти Е. Руланн зазначає, що влада над жертвою та кругова порука - це потужні детермінанти 
мобінгу, але для продовження й інтенсифікації процесу необхідною умовою $є$ також одночасне послаблення та нівелювання механізмів, які б стримували від застосування насильства й девіантної агресії щодо інших осіб [2].

До механізмів легітимізації зараховують заперечення відповідальності (у цьому випадку мобер презентує себе як жертву обставин, заперечує свій злий умисел або ж перекладає вину на інших); заперечення або мінімізацію завданої шкоди (коли відповідальності за скоєне уникнути не вдається, здійснюється прийом заперечення чи мінімізації шкоди); заперечення або екскатегоризацію жертви (у ситуаціях неможливості уникнення відповідальності за скоєне та заперечити або мінімізувати заподіяну шкоду мобер переключає свою увагу на жертву); осуд засуджуючих (мобер переключає увагу на тих, хто його засуджує); нейтралізацію девіантної оцінки поведінки посиланням на більш високі цінності (виправдання здійснюється через обґрунтування своїх дій вищими цінностями або необхідністю дотримуватися групових норм) [5].

Механізм перекладання відповідальності в ситуації мобінгу включається автоматично, адже цей акт агресії чи насильства здійснюється групою осіб, отже, тут наявний ефект групової відповідальності та кругової поруки. Цей механізм легітимізації насильницької та агресивної поведінки ніби «вмонтований» у сам процес мобінгу.

Дослідження доводять, що найбільш розповсюдженим механізмом легітимізації мобінгу серед дітей є звинувачення жертви [8]. Прийомами такого механізму $\epsilon$ «провокування жертви», «знайти гріхи минулого» й «розпізнати прихований ворожий мотив». Як правило, для цього використовуються раніше сказане чи зроблене жертвою, яке зазнає значного перебільшення, виривання з контексту окремих слів. Вчинки та дії жертви спеціально інтерпретуються переслідувачами хибно, щоб отримати підставу почати напад. При цьому жертва в завідомо програшній ситуації, що б вона не робила. Виправданню й легітимізації акту мобінгу сприяє також подальше обговорення та аналіз ситуації в колі однодумців: так мобер отримує підкріплення і схвалення своєї поведінки від оточення. Саме розмови про акт знущання пролонгують негативні соціальні й психологічні наслідки цькувань для жертви та бажаний ефект для мобера.

Дегуманізація і стигматизація жертви - це також один із часто використовуваних моберами механізм легітимізації насильницьких та агресивних дій. Соціальне дистанціювання від жертви й перетворення її з суб'єкта на об'єкт як сприяють інтенсифікації знущань, так і впливають на динаміку посягань. Дистан- ціювання від жертви та визнання ії «інакшості» може відбуватися не одразу й наростати поступово, так полегшуючи для моберів знущання та нівелюючи як внутрішні, так і зовнішні бар'єри насильства та агресії. «Вони не такі як ми, отже, не заслуговують на співчуття...» [2]. Акт насильницької поведінки, який здійснюється під час безпосереднього контакту між мобером і жертвою, завжди ускладнюється «конфронтаційним напруженням», яке пов'язано з різними цілями суб'єктів такої взаємодії [9]. Високе емоційне напруження безпосередньої взаємодії призводить до частого переведення актів мобінгу в дистанційну форму, зокрема у площині соціальних мереж. Такі акти насильства мають більш латентний характер, їх можуть не помічати вчителі й інші дорослі, але навряд чи ми можемо говорити про полегшені негативні наслідки для жертв таких цькувань. Платформи соціальних мереж передбачають включеність у певну віртуальну соціальну групу, «на очах» якої все відбувається, що забезпечує для моберів і жертв ефект публічності знущань із відповідними надбаннями й утратами, як і в реальному житті.

Проте подолання бар'єра конфронтаційного напруження можливе не тільки через перенесення насильства у віртуальну площину, а й через підбір інших тактик зменшення напруження. Відповідно до тактик зменшення напруження, виділяють різні типи насильства відповідно до пріоритетного вибору: по-перше, слабкої жертви, стосовно якої можливий емоційний контроль; по-друге, орієнтації на глядачів, які спонукають до насильства; по-третє, установлення просторової дистанції; по-четверте, скритності та приховування, вдавання, що конфлікту не існує [10].

Мобінг належить до перших двох типів насильства, які $€$ більш складними з погляду емоційного напруження, що, можливо, передбачає підвищену потребу у виправданні подібних дій і спричинює складний процес легітимізації, який закріплює певну когнітивну таповедінковусхемудевіантноїагресивноїреакції.

Доведено, що мобери й булери - це в основному діти, які пройшли досить успішну соціалізацію, комунікабельні, затребувані в групі однолітків і користуються повагою й підтримкою не тільки однокласників, а й учителів. Проте соціальний та інтелектуальний ресурси можуть слугувати інструментами досягнення різних цілей: як позитивних, так і негативних [7]. Комплекс просоціальних характеристик не здатен утримати їхні девіантні прояви насильства й агресії. Очевидно, що в осіб, які демонструють насильство, $є$ специфічний комплекс особистісних, соціальних характеристик і ситуативних інтерпретаційних елементів. Проте більшість із них прагне поваги 
та застосовує насильство саме заради демонстрації сили й утвердження чи підтвердження свого статусу. Група моберів виробляє певне зведення правил у тій чи іншій ситуації. Ключовою метою групового цькування в присутності свідків є підтвердження привілейованого статусу у своєму соціальному оточенні або ж самоствердження. Необхідною умовою привілейованості $є$ певний набір ритуалів взаємодії всередині мікрогрупи та ритуалів взаємодії з іншими особами. Якщо ці правила спілкування хтось порушує, то «відновлення» справедливості потребує помсти. Часто ті, хто ігнорує привілейованість роберів, ризикують стати жертвою.

Варто відмітити, що найменше суб'єктом насильства рефлексуються саме «неочевидні» форми насильства, які часто є частиною процесу мобінгу, а саме: «інформаційне насильство» - нав' язливе надмірне повчання й інформування щодо негативних сторін життя та його законів; «байдужість як насильство» та прояви пасивної агресії [11]. Такі форми насильства й пасивна агресія як компоненти мобінгу можуть часто застосовуватися комплексно з фізичною, вербальною агресією та насильством або ж можуть слугувати першим кроком до мобінгу над жертвою. Важливо, що мобером ці вияви або ж не рефлексуються взагалі, або ж легко легітимізується (з формулюванням: «я нічого поганого не робив») 3 подальшою інтенсифікацією.

У результаті досліджень механізмів виправдання власної агресивності С.М. Еніколоповим та Н.В. Чудовою з'ясовано, що «в людини, яка визнає свою готовність до фізичної агресії, основу її уявлень про агресію становить те, що можна назвати «теорією доброчинності насильства»». Дані, отримані дослідниками за допомогою опитника легітимізації агресії «ЛА-44», дали змогу зробити висновок, що «ЛА-44» дає можливість описати схильність до фізичної агресії, яка проявляється і як компонент «я», а також як уявлення про позитивну та «доброчинну роль» фізичного насильства в житті людини й держави, а також уникнення відповідальності в ситуації фрустрації. «Можна говорити про існування двох механізмів легітимізації власної агресії: імпліцитна теорія «доброчинності фізичного насильства», що обслуговує таку форму агресивності, як схильність до фізичної агресії, другий механізм, характерний для агресивності у формі ворожості, $€$ механізмом «перетворення побоювань у реальність» [12].

3 метою уточнення проблеми легітимізації та виправдання мобінгу у 2019-2020 рр. нами проведено опитування серед учнів старших класів у містах Ужгороді та Мукачево. Вибірка становила 150 осіб, серед них - 48 юнаків і 102 дівчини. Респондентам запропоновано опитник, який містить питання з окресленої проблематики, методику дослідження рівня агресії Басса-Перрі [13] і методику «ЛА-44» для дослідження проблеми легітимізації агреciї [4]. У процесі дослідження ми отримали такі результати: 77\% респондентів уважають насильницьку поведінку необхідною в деяких випадках, 88\% відмітили, що невинні жарти в більшості випадків переходять у відкрите кепкування, 64\% вказали, що потрапляли в ситуації, коли гуртом з іншими провчили «невдаху», 31\% уважають необхідним показати невдасі його місце за допомогою сили. Кореляційний аналіз Пірсона показав зв'язок рівня ворожості з легітимізацією агресії у виховній сфері ( $r=0,382, p<0,01)$, при цьому цікавим $€$ обернений зв'язок між рівнем легітимізації насильства в політичній сфері з кількістю членів у сім'ї респондента $(r=-0,310, p<0,01)$ та обернений зв'язок між легітимізацією агресії в спортивній сфері та наявністю друзів серед однолітків ( $r=-0,326, p<0,05)$, тобто, чим вищий рівень легітимізації, тим імовірніша наявність друзів. Виявлено зв'язок між рівнем легітимізації агресії у спорті й ігноруванням, яке демонструють особи щодо інших ( $r=0,303$, $\mathrm{p}<0,01)$. Також виявлено зв'язок між звичкою придумувати смішні прізвиська іншим і рівнем легітимізації агресії за шкалами опитника «ЛА-44»: власний досвід $(r=0,347, p<0,01)$, спорт $(r=0,327, p<0,05)$, 3MI $(r=0,321$, $p<0,05)$, інтегральна шкала $(r=0,303, p<0,05)$. Наділення людини кумедним прізвиськом тільки на перший погляд необразливий акт поведінки, насправді ж це вияв вербальної непрямої агресії, що часто є частиною мобінгу, який може бути пролонговано в часі за рахунок «прикріплення» цього прізвиська, так званого «ярликування». Окремі дослідження показують, що вже в дитячому садочку мобери наділені досить високим рівнем соціально-когнітивних навичок і надають перевагу непрямим формам цькування.

Висновки 3 проведеного дослідження. Легітимізація мобінгу - це обґрунтування прийнятності, виправданості й необхідності своїх тривалих насильницьких чи агресивних цькувань, а також виправдання себе і своєї ролі в процесі мобінгу, надання своїм діям ознак «нормальності» й «законності» за допомогою певних механізмів: «жертва обставин»; мінімізація завданої шкоди; звинувачення жертви; звинувачення свідків; осуд тих, хто засуджує; покладання на вищі цінності; «героїзація мобера», дистанціювання; перекладання провини. Легітимізація мобінгу є одним із потужних детермінант відтворення цього явища. При цьому специфіка мобінгу та його структура передбачають певні легітимізуючі меха- 
нізми, які включено в його сутність. Легітимізація девіантної агресії та насильства, мобінгу зокрема, призводить до вкрай негативних наслідків переформатування соціальної норми щодо цих явищ як на індивідуальному, так і на мікросоціальному рівнях. Розуміння процесу виправдання й легітимізації мобінгу може частково або повністю нівелювати його негативний ефект, сприятиме запобіганню сприйняттю його як варіанта норми та недопущення сприйняття його як варіанта норми.

\section{ЛITEPATУPA:}

1. Olweus D. Mobbing in Schulen: Fakten und Intervention. Henschel A., Krüger R., Schmitt C., Stange W. (eds) Jugendhilfe und Schule. VS Verlag für Sozialwissenschaften. 2008. 247-248 S.

2. Руланн Э. Как остановить травлю в школе: психология моббинга / пер. с норв. Москва : Генезис, 2012. C. 119.

3. Nigoff A. Social Information Processing and Aggression in Understanding School Violence: An Application of Crick and Dodge's Model. Miller T.W. (eds) School Violence and Primary Prevention. Springer, New York, NY, 2008. P. 79-93.

4. Ениколопов С.Н., Цибульский Н.П. Изучение взаимосвязи легитимизации насилия и склонности к агрессивным формам поведения. Психологическая наука и образование. 2008. Том 13. № 1.
5. Sykes G. \& Matza D. Techniques of neutralization: A theory of delinquency. Ameri can Sociological Review. 1957. V. 22.

6. Гилинский Я.И. Социальное насилие. СанктПетербург : Алеср-Пресс, 2013. 185 с.

7. Malti T., Perren S. Soziale Kompetenz bei Kindern und Jugendlichen. Stuttgart : Kohlhammer, 2008. 280 S.

8. Gini G., Pozzoli T. Association between bullying and psychosomatic problems: A me taanalysis. Pediatrics. 2009. № 123. 1059-1065.

9. Collins R. Interaction Rituals and the New Electronic Media. URL: http://sociological-eye.blogspot.com/ 2011/01/interaction-rituals-and-new-electronic.html.

10. Collins R. Entering and leaving the tunnel of violence: Microsociological dynamics of emotional entrainment in violent interactions. Current sociology. L., 2013. Vol. 61. № 2. P. 132-151.

11. Герасіна Л.М. Насильство як соціальна деструкція. Вісник Харківського національного універcumemу ім. В.Н. Каразіна. Серія «Соціологічні дослідження сучасного суспільства: методологія, теорія, методи». Харків, 2015. № 1148. Вип. 34. С. 35-41.

12. Ениколопов С.Н., Чудова Н.В. Агрессивность и имплицитная теория насилия. Прикладная юридическая психология. 2017. Т. 39. № 2. С. 18-26.

13. Ениколопов С.Н., Цибульский Н.П. Психометрический анализ русскоязычной версии Опросника диагностики агрессии А. Басса и М. Перри. Психологический журнал. 2007. № 1. С. 115-124. 